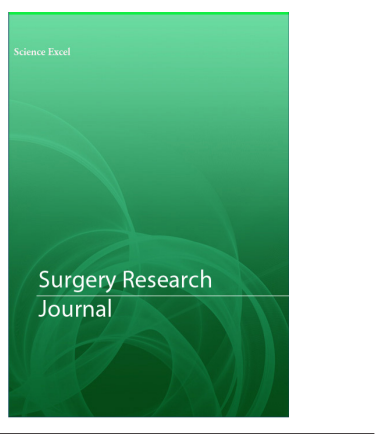

Correspondence

Thomas Wenzel

World Psychiatric Association Scientific Section on Psychological Aspects of Torture and Persecution, Austria, Tel: 0043140400 37230.

E-mail: drthomaswenzel@web.de

- Received Date: 02 June 2020;

- Accepted Date: 20 June 2020;

- Publication Date: 22 June 2020

Keywords

Torture, Disaster medicine, Medical ethics, Forensic medicine, Trauma.

\section{Copyright}

(C) 2020 Science Excel. This is an openaccess article distributed under the term of the Creative Commons Attribution 4.0 International license.

\title{
The role of surgeons in the medical documentation of torture- UN standards
}

\author{
Thomas Wenzel ${ }^{1,3^{*}}$, Reem Alksiri ${ }^{1,2}$, Siroos Mirzaei ${ }^{3,4}$ and Joost den Otter ${ }^{1}$ \\ 'World Psychiatric Association Scientific Section on Psychological Aspects of Torture and Persecution, Austria \\ ${ }^{2}$ Syrian Woman's International Initiative, Austria \\ ${ }^{3}$ Amnesty Medical Group Austria, Austria \\ ${ }^{4}$ Wilheminenspital der Stadt Wien, Vienna, Austria
}

\begin{abstract}
Rationale: In the article, the authors present the relevance of the frequently neglected UN and World Medical Association standard for the documentation of torture related injuries, the Istanbul protocol. Objectives: We aim at summarising the relevant key aspects of this important standard for surgeons in preserving evidence and fulfilling their ethical obligations as medical doctors. We find the instrument clear and relevant and highlight the need of an interdisciplinary approach in the documentation and prevention of torture.

Conclusions: The Istanbul protocol is an important standard that should be known and used in clinical practice whenever confronted with possible or alleged sequels to torture an can also improve the understanding of often underrated forensic procedures and the possible contribution of their field for surgeons and other health professionals, not only for forensic experts.
\end{abstract}

\section{Introduction}

In spite of the absolute and comprehensive prohibition against torture, as outlined for example in the UN Convention against Torture and Inhuman and Degrading Treatment [1,2], and corresponding frameworks in international humanitarian and human rights law, including that of the EU [3], torture, with its severe immediate and long-lasting consequences, is unfortunately still a common practice in many countries [4]. Medical doctors have not only an obligation not to participate in torture in any capacity, but also to stop the practice and report on torture and document possible injuries and health results of torture $[5,6]$, as underlined as professional standard for example in the World Medical Association (WMA) hand book on ethics (https://www.wma.net/what-we-do/ education/medical-ethics-manual/). This can lead to conflicts especially in "doctors at risk" to participate in or hide torture in prisons or police stations, especially if they are employed by governmental agencies [7-9]. Compliance with ethical standards might require courage and international support for medical doctors who are threatened with sanctions when they comply with the above ethical standards. Especially doctors in prisons and other places of detention including asylum related detention places should be made aware of this obligations [10], that cannot be suspended with any justification such as for example in case of " $[11,12]$ national emergencies" or the so called "war against torture" $[7,13]$. The special UN guidelines for conditions in prisons- the Minimum Standard Guidelines for the Treatment of Prisoners (Mandela Rules, A/RES/70/175), and for female prisoners, the "Bangkok rules" [14] should further be considered in this context. The prosecution of doctors who violate this principles and the protection of those participating in the fight against torture even at personal risk must in this context be seen as insufficiently implemented. The arrest of even medical doctors active in disaster medicine in countries like Iran during international medical conferences underlines the insufficient protection mechanisms for medical doctors in spite of the immediate reactions of the World Medical Association (https://www.wma. net/news-post/wma-urges-iran-to-stop-denyingmedical-care-to-prisoners/).

The United Nations have published further standards that should be used by health care professionals in this context, and are expressively supported by the WMA, World Psychiatric Association and other professional umbrella organisations. A) The Minnesota protocol (UN Manual on the Effective Prevention and Investigation of Extra-Legal, Arbitrary and Summary Executions [15]) is the framework for the examination of deaths suspicious of being due to torture or other human rights' violations, while B), the recently updated "Istanbul Protocol" [16-20] guides the documentation of suspicious injuries, the writing of records, and the obligatory process of conducting an independent, immediate and effective investigation. An effective independent 
investigation based on good forensic evidence can contribute under good circumstances to an immediate stop to further abuse and a court case against the perpetrators, though in countries where the rule of law has broken down or is circumvented, such medical evidence can only be used by international courts of in the new process of Universal Jurisdiction, when the general prosecutor in a third country starts an investigation to indict perpetrators in the country where torture has been used (Figure 1).

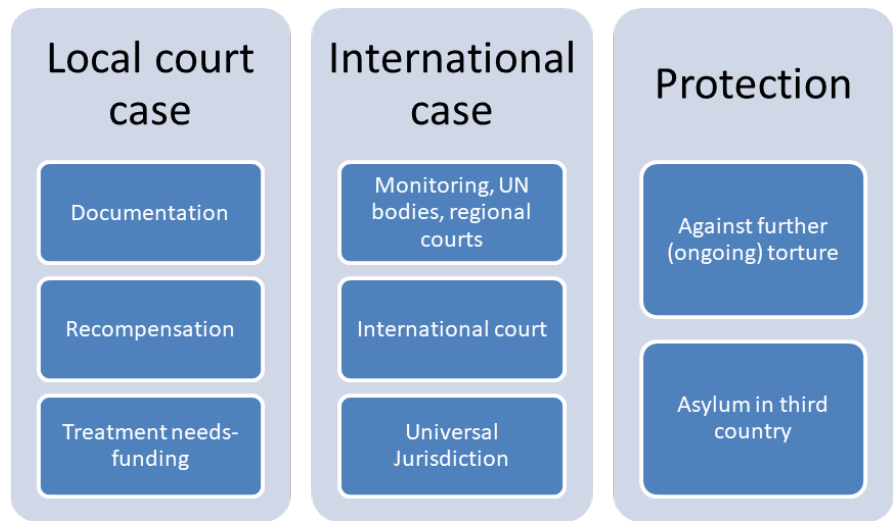

Figure 1: Use of medical expertise in documenting torture.

As physical torture frequently leads to severe injuries to joints, tissue and bones, surgeons are important in the correct and rapid documentation of these injuries [21]. This must be seen as securing evidence, as many traces will vanish or change appearance with time, so fresh injuries properly documented can play a decisive role in the fight against torture and any later investigation or future court case. The basic documentation of (fresh) injuries by any competent person (in some cases even by lay persons) can be crucial for a later more comprehensive forensic report [22].

While the use of torture and similar extreme human rights' violations is most commonly associated with dictatorships and civil war areas such as Syria [23-25] or Iran [26-28], it also is reported though in much rarer instances in other like European countries [29], Australia [30], or the US [31]. Further, injuries related to torture or other acts of persecution or to war can be an important element of proof of persecution relevant for a claim of protection in asylum cases $[22,33]$.

The Istanbul protocol should therefore be part of all medical primary education and of life-long learning and a number of international, especially of EU projects have been implemented to raise awareness and increase the knowledge of the protocol [17]. While the principle guidelines of the IP can be seen as Universal, specific knowledge of regional practices of torture, like the "German chair" leading to damage to joints by overstretching and fractures or falanga $[34,35]$, (beatings to the soles of the feet with destruction of plantar tissue and characteristic long term sequels) might be helpful or even essential to recognise specific forms of torture.

In these cases, basic descriptive, radio imaging and photographic documentation might play an even more important role. Specific injuries are also caused by application of tasers or other forms of electrical torture and should not be overlooked [36,37]. Chronic pain after torture is common and requires comprehensive interdisciplinary assessment and treatment [38-40].

Bone scintigraphy has been reported to be especially efficient in recognising and documenting blunt bone injuries after torture [41,42], as also in child abuse and should be considered [43], especially if injuries are related to reported torture that was afflicted not longer than a about decade ago (Table 1).

\begin{tabular}{|c|c|}
\hline I & Relevant Legal Standards \\
\hline II & Relevant Ethical (including medical ethical) Standards \\
\hline III & Legal Investigation of Torture \\
\hline IV & General considerations for interviews \\
\hline V & Physical Evidence of Torture \\
\hline VI & Psychological Evidence of Torture \\
\hline & Annexes \\
\hline
\end{tabular}

Table 1: Structure of the Istanbul Protocol

(https://www.ohchr.org/documents/publications/training8revlen.pdf).

In this context, it is important to keep in mind, that a negative finding must not disprove details in reports of alleged torture, especially as memory can be unreliable due to factors like disorientation during torture, blunt brain injury, (posttraumatic) stress related disorder, or other disorders leading to impaired memory and concentration like also for example diabetes $[17,44,45]$. Further it must be considered, that in some countries, especially those where torture is still effectively sanctioned or officially discouraged, torturers increasingly try to use methods that lead no clear physical traces [4]. This aspect also underlines the importance of a comprehensive interdisciplinary examination that always must include a mental health examination [4]. Mental health sequels to torture are as relevant as physical injuries, especially as they are as part of the evidence, common, long lasting, and also influence the ability to describe alleged torture and medical history in general, and are especially relevant in later, delayed examination [4]. They have to include culture specific aspects $[17,46]$. The rapid and "as detailed as possible" physical examination by the surgeon in turn is crucial to preserve the evidence of injuries healing and changing their appearance over time and should be accompanied by photographic documentation [47]. In this context, a simple photographic series, even with a good cell phone camera, is better than no such document. Standard approaches in taking forensically useful pictures underline the importance of a basic strategy that improves documentary evidence significantly: a) start with an overview of the whole body region or body, before taking in-detail pictures, b) use a forensic or even simple ruler with colour comparison element, c) ensure integration with report and findings (which injury was done by whom? how? when?). In prison visits, possible tools used in torture should, if possible, be identified and documented.

\section{Conclusions}

Medical doctors and especially surgeons play an important role in the recognition, reporting and documentation of injuries suspicious of torture and similar human rights violations and therefore in the fight against torture. Institutional or other pressure against drawing attention to torture or refusing any form of participation might create difficult situations, but must be balanced against medical professional ethics that clearly defines the role of professionals in this context. The UN Istanbul and Minnesota protocols give clear frameworks of reference to guide not only forensic experts, but all medical doctors and provide an interdisciplinary framework in this context.

\section{References}

1. Rasmussen OV. The medical aspects of the UN Convention against Torture. Torture. 2006; 16: 58-64.

2. Human Rights Commission of Pakistan. UN convention against torture and other cruel, inhuman, or degrading treatment or punishment. Human Rights Commission of Pakistan, Lahore, 1996; pp: 19. 
3. Harding TW. Prevention of torture and inhuman or degrading treatment: medical implications of a new European convention. Lancet. 1989; 1: 1191-1193.

4. Wenzel T. Torture. Curr Opin Psychiatry. 2007; 20: 491-496.

5. Iacopino V, Xenakis SN. Neglect of medical evidence of torture in Guantanamo Bay: a case series. PLoS Med. 2011; 8: e1001027.

6. Dyer C. Doctors have authority to assess injuries from alleged torture, says Supreme Court. BMJ. 2019; 364: 11121.

7. Malke B. Ethical dilemmas for physicians in time of war. Isr Med Assoc J. 2010; 12: 172-173.

8. Miles SH, Alencar T, Crock BN. Punishing physicians who torture: a work in progress. Torture. 2010; 20: 23-31.

9. Polatin PB, Modvig J, Rytter T. Helping to stop doctors becoming complicit in torture. BMJ. 2010; 340: c973.

10. Berger Z, Rubenstein LS, DeCamp M. Clinical care and complicity with torture. BMJ. 2018; 360: k449.

11. Miles SH, Freedman AM. Medical ethics and torture: revising the Declaration of Tokyo. Lancet. 2009; 373: 344-348.

12. Editorial: The declaration of Tokyo: no truck with torture. Med J Aust. 1975; 2: 759-760.

13. Rubenstein LS, Xenakis SN. Roles of CIA physicians in enhanced interrogation and torture of detainees. JAMA. 2010; 304: 569-570.

14. Paynter MJ. Policy and Legal Protection for Breastfeeding and Incarcerated Women in Canada. J Hum Lact. 2018; 34: 276-281.

15. Keten A. Minnesota Autopsy Protocol. J Forensic Leg Med. 2020; 72: 101944.

16. Cryer R. International criminal law documents. Cambridge, United Kingdom ; New York, NY, USA: Cambridge University Press; 2019. pages $\mathrm{cm} \mathrm{p}$.

17. Wenzel T, Frewer A, Mirzaei S. The DSM 5 and the Istanbul Protocol: Diagnosis of psychological sequels of torture. Torture. 2015; 25: 51-61.

18. Moreno A, Crosby S, Xenakis S, et al. Implementing Istanbul Protocol standards for forensic evidence of torture in Kyrgyzstan. J Forensic Leg Med. 2015; 30: 39-42.

19. Haagensen JO. The role of the Istanbul-Protocol in the uphill battle for torture survivors being granted asylum in Europe and ensuring the perpetrators pay. Torture. 2007; 17: 236-239.

20. Iacopino V, Ozkalipci O, Schlar C. The Istanbul Protocol: international standards for the effective investigation and documentation of torture and ill treatment. Lancet. 1999; 354: 1117.

21. Kimmerle EH, Baraybar JP. Skeletal trauma : identification of injuries resulting from human rights abuse and armed conflict. Boca Raton: CRC Press; 2008. xxvi, 493 p. p.

22. Heisler M, Moreno A, DeMonner S, et al. Assessment of torture and ill treatment of detainees in Mexico: attitudes and experiences of forensic physicians. JAMA. 2003; 289: 2135-2143.

23. The L. Torture and ill treatment in Syria's prisons. Lancet. 2016; 388: 842

24. Edston E. Bodily evidence can reveal torture. 5-year experience of torture documentation. Lakartidningen. 1999; 96: 628-631.

25. Cohn J, Jensen R, Severin B, et al. Torture in Argentina, Syria and Zanzibar. Follow-up study of 3 persons. Ugeskr Laeger. 1978; 140: 3202-3206.

26. Dehghan R. The health impact of (sexual) torture amongst
Afghan, Iranian and Kurdish refugees: A literature review. Torture. 2018; 28: 77-791.

27. Busch J, Hansen SH, Hougen HP. Geographical distribution of torture: An epidemiological study of torture reported by asylum applicants examined at the Department of Forensic Medicine, University of Copenhagen. Torture. 2015; 25: 12-21.

28. Priebe S, Esmaili S. Long-term mental sequelae of torture in Iran--who seeks treatment? J Nerv Ment Dis. 1997; 185: 74-77.

29. Istanbul Protocol Project in the Basque Country Working G. Incommunicado detention and torture in Spain:Part I: The Istanbul Protocol Project in the Basque Country. Torture. 2016; 26: 3-7.

30. Berger D. Australia's torture of asylum seekers. BMJ. 2016; 354: i4606.

31. Moszynski P. Medical evidence exposes US use of torture. BMJ. 2008; 336: 1458-1459.

32. Clement R, Lebosse D, Barrios L, et al. Asylum seekers alleging torture in their countries: Evaluation of a French center. J Forensic Leg Med. 2017; 46: 24-29.

33. Peart JM, Tracey EH, Lipoff JB. The Role of Physicians in Asylum Evaluation: Documenting Torture and Trauma. JAMA Intern Med. 2016; 176: 417

34. Byard RW, Singh B. Falanga torture: characteristic features and diagnostic issues. Forensic Sci Med Pathol. 2012; 8: 320-322.

35. Amris K, Torp-Pedersen S, Rasmussen OV. Long-term consequences of falanga torture--what do we know and what do we need to know? Torture. 2009; 19: 33-40.

36. Pollanen MS. The pathology of torture. Forensic Sci Int. 2018; 284: 85-96.

37. Karlsmark T, Thomsen HK, Danielsen L, et al. Tracing the use of electrical torture. Am J Forensic Med Pathol. 1984; 5: 333-337.

38. Kaur G, Weinberg R, Milewski AR, et al. Chronic pain diagnosis in refugee torture survivors: A prospective, blinded diagnostic accuracy study. PLoS Med. 2020; 17: e1003108.

39. Amris K, Jones LE, Williams ACC. Pain from torture: assessment and management. Pain Rep. 2019; 4: e794.

40. Tsur N, Defrin R, Shahar G, et al. Dysfunctional pain perception and modulation among torture survivors: The role of pain personification. J Affect Disord. 2020; 265: 10-17.

41. Mirzaei S, Knoll P, Lipp RW, et al. Bone scintigraphy in screening of torture survivors. Lancet. 1998; 352: 949-951.

42. Lok V, Tunca M, Kumanlioglu K, et al. Bone scintigraphy as clue to previous torture. Lancet. 1991; 337: 846-847.

43. Ozkalipci O, Unuvar U, Sahin U, et al. A significant diagnostic method in torture investigation: bone scintigraphy. Forensic Sci Int. 2013; 226: 142-145.

44. Zandieh S, Bernt R, Knoll P, et al. Analysis of the Metabolic and Structural Brain Changes in Patients With Torture-Related Post-Traumatic Stress Disorder (TR-PTSD) Using (1)(8)F-FDG PET and MRI. Medicine (Baltimore). 2016; 95: e3387.

45. Wenzel T, Griengl H, Stompe T, et al. Psychological disorders in survivors of torture: exhaustion, impairment and depression. Psychopathology. 2000; 33: 292-296.

46. Mirzaei S, Hardi L, Wenzel T. How to combat torture if perpetrators are supported by a religious "justification". Torture. 2011; 21: 17317-7.

47. Moreno A, Grodin MA. Photo/essay: the not-so-silent marks of torture. JAMA. 2000; 284: 538. 